To be presented at the MT - 13 Conference, September 20-24, 1993

Victoria Conference Centre Victoria, B.C. Canada BRL -48863

\title{
Construction Details and Test Results from RHIC Sextupoles*
}

M. LINDNER, M. ANERELLA, G. GANETIS, M. GARBER,A. GHOSH, A. GREENE, R. GUPTA, A. JAIN,S. KAHN, E. KELLY, E. KILLIAN, G. MORGAN, A. PRODELL, M. REHAK,

K. ROBINS, W. SAMPSON, R. SHUTT, R. THOMAS, P. THOMPSON, P. WANDERER, E. WILLEN

RHIC Project

Brookhaven National Laboratory, Upton, NY 11973

Abotrect-Four $8 \mathrm{~cm}$ aperture cextupale have been bullt at BNL to vorify the magnetic parformance of the magat in the RErC inctallation. Two algnincantly difnerent mochnikeal configuratlone have been declored, and two manguets of each dealgn have baen bunt, and ancecurbilly teated, and have exceaded the required minimum quench current by a subitantial maryth. This report deweribes the awembly detalls of the wecond conflgarntion, which is the anal producthon configuration. In eddition the trat induntry bullt production cextupole has boen dellvered and teated. This report presents the results of quench tests on in s magnots and fleld meanurements on the inst production cextupale.

\section{INTRODUCTION}

The Relativintic Heery Ion Collider (RHIC) will be a colliding beam theility with detign energy of $100 \mathrm{X}$ $100 \mathrm{GeV} / \mathrm{a}$ for jous a heary a An. The tro accelerator/atorage rings are divided into "regular aren" and intersection regions. A set of 288 sertupole elements are ancescary to reduce the vatural chromaticity $(X \sim-12)$ and correct sertupole feld imperfections in the dipole magnets. These are positioned at every quadrupole in the regular ares, and have a deaign atrength of 850 TesL/meter with an inner bore of $80 \mathrm{~mm}$ and leagth of 750 mm. Thene superconducting magnets are conatrueted with the same overall dinmeter as the are quadrupoles, and are anembled in one eryogenic cold man with the are quadrupoles and corructors.

\section{DEgTGN}

Twble 1 biate the becic parameters of these sextupoles. The baic mechine requirement is for sextupoles with 80 $\mathrm{mm}$ bore and decign atrength of $550 \mathrm{~T} / \mathrm{m}$ (bi-polar). The power lads are brought ont of the eryontat for each individual unit. Hence, to minimise the exyogenic load the excitation current must be kept mall - thin forces - vire (as opposed to cable) coil with many turns. The overall bength in aleo opecinied by the machine lattice. The aperture and the outer phycical diameter are chosen to match the othor are components.
Table 1: Parameten of RAIC ARC SEXTUPOLES

\begin{tabular}{|c|c|}
\hline Parameter & Value \\
\hline Wire Diameter & $0.50 \mathrm{~mm}$ \\
\hline Copper to SuperConductor & 3:1 \\
\hline Ic(2.0 Teals) & $230 A$ \\
\hline Turns per layer & 20 \\
\hline Leyers per coil & 10 \\
\hline Number of turns per pole & 200 \\
\hline Coils per magnet & 6 \\
\hline Clear Bore & $80 \mathrm{~mm}$ \\
\hline Length & $750 \mathrm{~mm}$ \\
\hline Dexign Current & $100 \mathrm{Amp}$ \\
\hline Design Integral Strength & 554 Teale/meter \\
\hline Quench Current & 195 Amp \\
\hline Quench Integral Strength & 780 Teale/meter \\
\hline $\begin{array}{l}\text { Integral Strength } \\
\text { for Dipole b2 swing }\end{array}$ & 140 Teal /meter \\
\hline $\begin{array}{l}\text { Integral Strength } \\
\text { for Chromaticity }\end{array}$ & 160 Teal/meter \\
\hline $\begin{array}{l}\text { Inductence at } 0 \text { Amp } \\
\text { Inductance at } 100 \mathrm{Amp}\end{array}$ & $\begin{array}{l}815 \mathrm{mH} \\
530 \mathrm{mH}\end{array}$ \\
\hline Number for RHIC & 288 \\
\hline
\end{tabular}

\section{A. Magnetic Design}

For maximum simplicity, - layer wound recetrnck coil was chosen. This fte over the sheped iron pole tip. At low field, the pole tip dominates the fleld, reducing the cencitivity to coil locution erron. Becanse of mechnnical limitations, the actual pole tip is narrower than optimum. This reults in very noticenble enturation. The neck of the pole tip (coe Fis. 1) enturates at ebout 80 Ampa. It leo produces a noticenble con $9 \theta$ term (vithin accelerator tolerance). For mochanical compatibility, the yoke is much larger than it need to be to provide an adequate return path. The iron pole tip in theee magnets combined with the magnetination curnents is the auperconductors prodnce hysteresie and recidual flelds. However, though bipolar in general, individual sertupoles woully will have fred polarity in the accelerator.

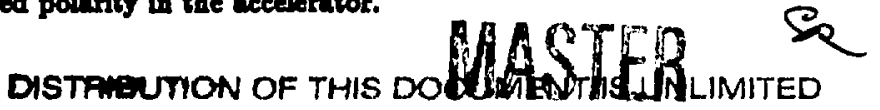




\section{B. Mechenical Design}

For the RHIC are magmets, the philosophy is to use as much as pousible of the dipole technology for the rest of the components. Hence, the eertupole yoke differs only in detail from that of the dipale. The $8 \mathrm{~cm}$ saxtupole is constructed as a modular subescembly, joined at final nenembly with the quadrupole and corrector units.

1) Magnet Derign: The magnets are built in two role halves(Fis. 1, which are almost identical in detail. In order to obtain the desired sextnpole field, the magnet belves each contain three experconducting wire-wound coit. Trease coil are connected to provide the magnetic polarity required for the magnet.

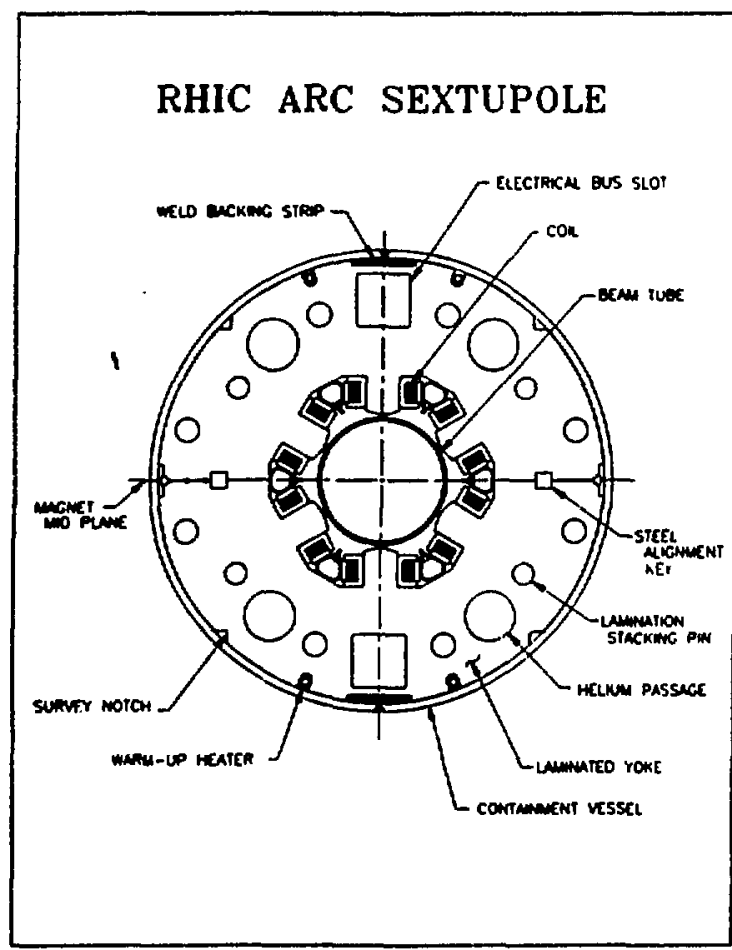

Cigure 1s Crom wetion of RHIC axe sextupole.

8) Irom Ices: The iron man of the roke half is divided into modulen, made up of atacks of ahoet steel laminations $1.8 \mathrm{~mm}$ thick. Thewe ntack are carefolly controlled to keep the iron quantitie (weighte) uniform, for consintent performance, and are held together by means of bow carbon steel pine, staked at the enda. The huminations contain all the necenary contours and detail to provide for pole piecen, coil seats, helinm bypan holen, anombly holes and reference tats for anembly and survey. A aumber of thew modules are pleced on eccurately mechied rails for anembly. Bnd modules, which here no pole piecen but ase otherwive identieal in chepe to the middle modules, are placed at the ends of the yole half stack. Tooling rods and plates are employed to keep the entire yole half stack together for subsequent ascembly operations. To this point, the upper and lower yoke halves are identical.

s) Coils: The vire is wrapped with Kapton insulation and then fiberglas tope. The coils are layer wound on mechined epory fiberghes (G-10CR or G-11CR) coil form, carefally controlled to prevent wire croscovers. Each layer of wire is covered with a layer of fiberglass tape, which is impregnated with liquid epoxy immediately before installation, to provide a stable base for the next layer of wire. Ten sueh layers are built-up, for a total of 200 turn of wire per coil. Coil elomure is efiected by means of that stripe of epory fiberglas inserted into the coil wire apace and compreased to form the virea and fiberglass tapes into a dense mass. To this point, all the coils are identical as to winding direction, number of turns and sire. After the epory has hardened, the rires are brought out to a terminal bourd where the connections determine whether the coil in an " $A$ " or "B" coil, " $A$ " and " $B$ " derignating coil polarity. The coils are then individually teated for reaintance, and inductance. The ende of these coils are unuupported, the Lorents forces are hoop strea in nature, and the quench performance of the coil is determined by the center section.

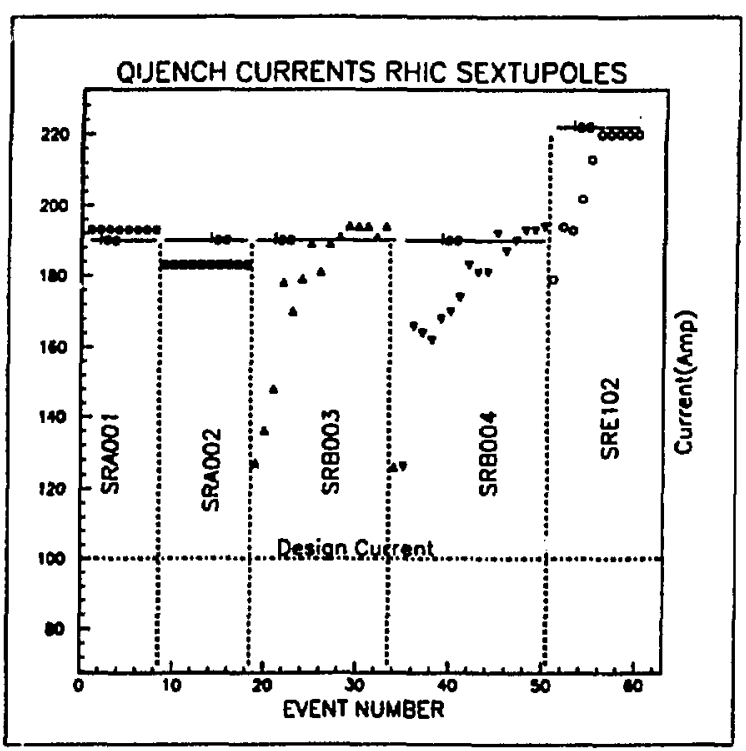

Figure 28 Quench currents for RHIC sextrpoles. Decign current allows $50 \%$ margin above normal operation. Note the supprewed sero.

4) Yolve Half Acuembly: The yoke half rtacks are placed on anembly railn, and coils are installed on the pole pioces. Depending on whether the half steck is "upper" or "lower", the coil complement is 2 "A" coils and 1 " $B$ " coil for the upper, and 1 " $A$ " coil and 2 " $B$ " 


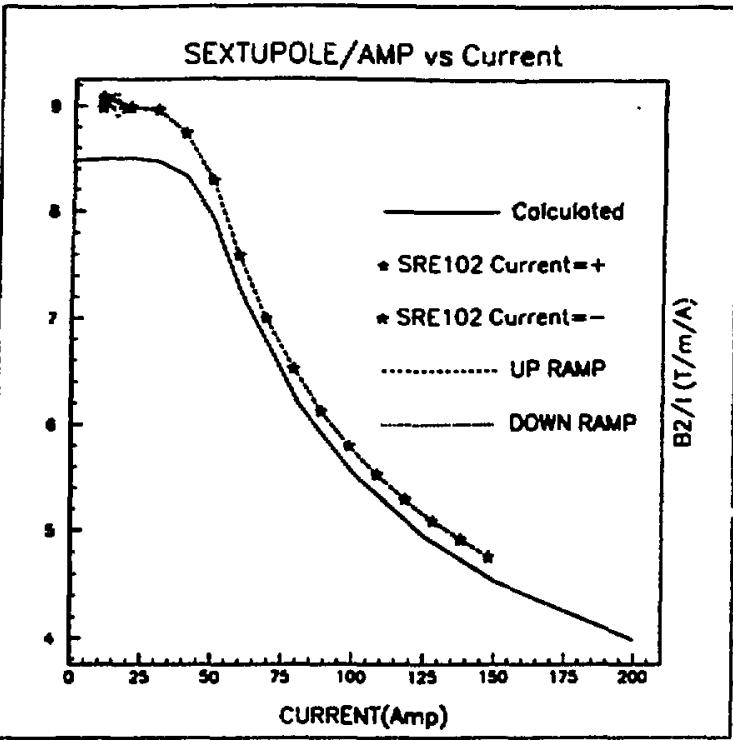

Figure 3: Calenlated and measured integral sextupole strength. Note the small hystereais.

1

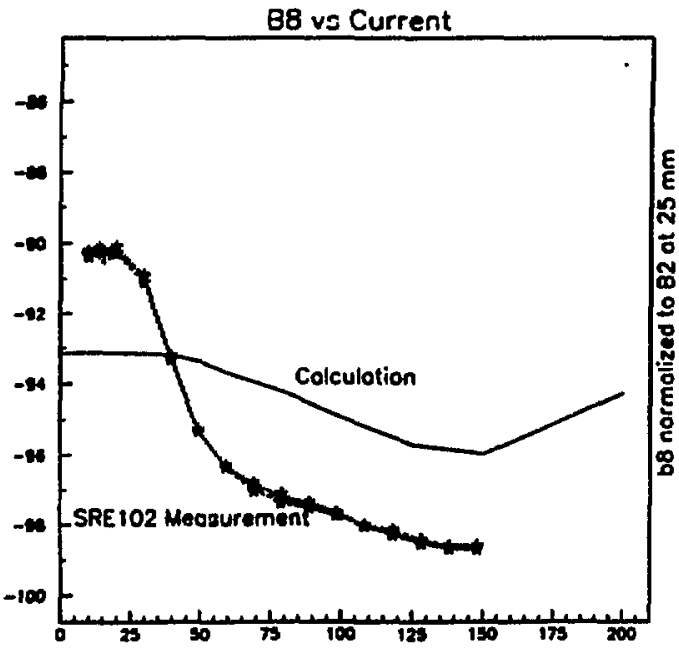

Fisure is Comparicon of measured and calculated thrt (b6) allowed harmonic. The ealenlation is for the center of the megnet, the meanrement includes the efiects of the ends.

coila for the lower half. End Allers are installed at this point to keep the coils from shifting axilly. These fllers are machined epoxy fiberglaw, and are cemented in place with on epoxy containing an inorganic filler.

Dee to the fleribility of the long sides of the wound coil, the coil in restrained with an elantic member that revists the Lorents forces generated during operation of the magnet. At quench these forces are $80 \mathrm{kN} / \mathrm{m}$ at 45 from radial. After come developmental studies, the restruint that evolved was a simple spring shape that slides into place in an arial direction, and in retained by a carefully shaped wedge which is held in place by having the apex angle belor the angle of repose. The redge needs only to be pushed into place by a ball-ended tool, and remain there until foreed ont by deliberate action. The opring, which develops eome $35 \mathrm{kN} / \mathrm{m}$ to resint the Lorents force, is fabriented from beryllium copper, then heat treated. The wedge is precicion extruded alnminnm alloy. This retainer design allows the replacement of any extupole coil withont complete diraeembly of the magnet.

Since both yoke halves are asembled with the midplane open, it is necemary to invert the upper half for asembly. The tooling provided to support the apper half module asemblies incorporates stub shafts to allor the npper helf to be lifted of the asembly rails, rotated about its longitudinal axis, and then lowered into place on the lower half. After alignment, the two balves are joined by small fillet welds, spring coil retainers that bridge the mid-plane are installed, and end plates are welded into place. Inntallation of a fiberglars terminal board, and wiring of the coile, are all that remain for completion of the sextupole tuagnet axc.nbly.

\section{Quench Result.}

The results of quench teating are sumpuarised in Fis. 2. In this figure $I_{1,}$ denoted the colenlatel limiting carrent based on the measured rire short sample Ic2. Numerons $(\sim 100)$ quenchs on the plateanx have been omitted for clarity. SRAOOL and SRAO02 were built with the earlier restraint system and the coill were either built in house or re-worked in house, they have excellent quench behavior. SRBO03 and SRBO04 were built as pre-production prototypes. In thewe magnets, the onter enrface of the coil was not compreaned during cure: the loosenen is reflected in the rather extensive training. Note that the lowest quench is atill $125 \%$ of deairs. SRE102 is the finst rextupole made wholly by induntry (Everwon Blectric). Its fint quench at $\mathbf{1 8 0 \%}$ of design is oututanding.

\section{Magnetic Field Result:}

The fre cextnpoles hsve bean measured with rotating coils both at room temperature and at $4.2 \mathrm{~K}$, with good agreement between the two meanrements. Only the date for SRE102 is presented (the fieldo for the earlier magnets are similar). 


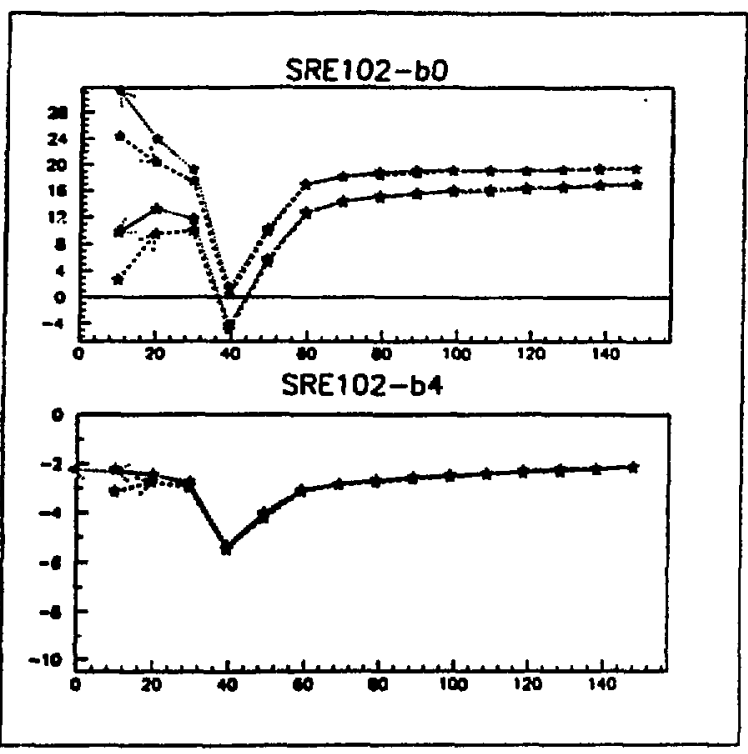

Tigure 8: Dipole and Decapole components. The origin of the sharp dip at $\mathbf{1 0}$ Ampe is unexplnined.

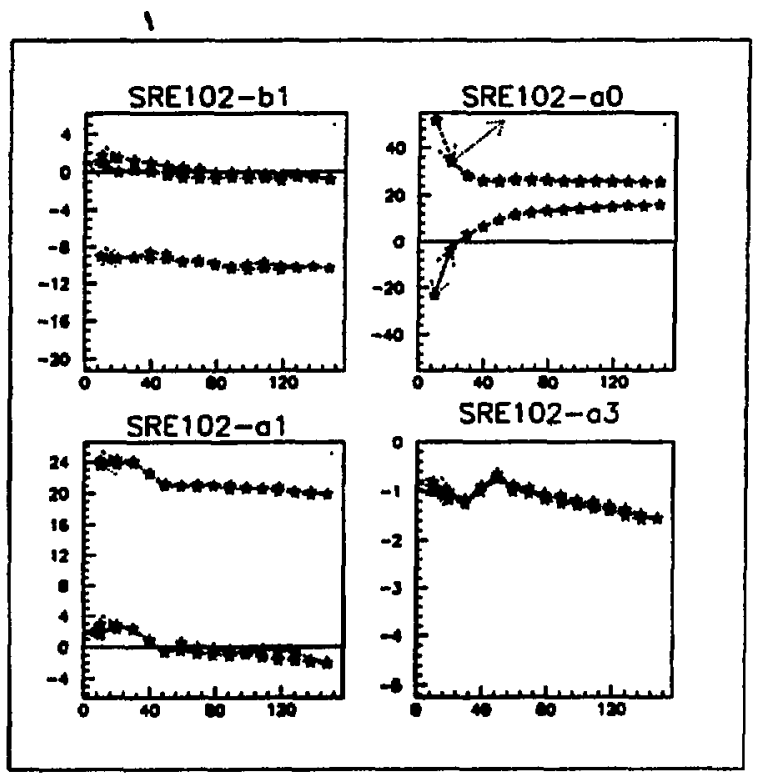

Figure of Intereating non-ellowed Aarmonics. Note the abeence of any dip at $40 \mathrm{Amps}$.

1) Seatrole Term: The trander function is plotted in Fis. 3. In this and subequent figures, the data are integral(ie. intecrated with a moasuring coil signiflcantly longer than the magnet). The units of sertupole are thas $T / m$. The ealeulations are only done for the straight section, hence it is to be expected that the measured fundamental is a few percent larger. The strong saturation arise from the "neck" of the pole tip which is narrower than optimum. The measurements cover both up and down sweepe and negative and poaitive currents. The residual fields are barely apparent at 10 Amp:.

2)68-First Allowed Barmonic: Another result of the narrow pole tip is the large B8 term even at low field. The iron saturation is apparent. The difference between calculation and measurement is due to the ends which have a large poritive b8.

s) Other Barmonics: The most interenting forbidden harmonics are bo and b4 shown in Fig. 5 . In these figures, the open symbols are the data for positive current, and the dached lines are for the up ramps. The dipole(bo) term is unexpectedly large. There is no undertood cource for this. The sharp dip at $\mathbf{4 0} \mathrm{Amps}$ was reen in SRB003 and SRBO04. It is not underatood. A dip also appears in the decapole (b4) data at the same current. Theac intereating effects are well within the accelerator tolerances.

Fig. 6 shows additional non-sero harmonics. These are all forbidden by symmetry. The tails at low eurreats in the $\mathrm{a} \mathrm{O}$ data are either reaidual fields or superconductor megnetiration. In either care they imply an ap-down aymmetry.

\section{v. CONCLUSIONS}

A succeseful decign for $550 \mathrm{~T} / \mathrm{m}$ sextupole has been developed. The 288 of theae magnets needed for the accelerntor are nor in rontine prodnction. The first production magaet renched $180 \%$ of deviga right "ont of the box". Some of the harmonica are not yet explained but they are wall within accelerator tolerances

\section{APPENDIX}

The fteld on the midplane of a sextupole can be expresced as:

$$
\begin{aligned}
& \mathrm{B}_{y}=\mathrm{B2} \mathrm{b}_{n}{ }^{\prime} \times 10^{-4}(\mathrm{z} / \text { Rref })^{\mathrm{N}} \\
& \text { (the } \cos (n+1) \text { term) } \\
& \mathrm{B}_{\text {. }}=-\mathrm{B} 2 \mathrm{n}^{\prime} \times 10^{-1}(\mathrm{z} / \text { Rref })^{\mathrm{n}} \\
& \text { (the } \sin (n+1) \theta \text { term) }
\end{aligned}
$$

B2 = Sextupole strength at Rref $=25 \mathrm{~mm}$. With this deffnition, the "primed units" represent the field devintion menured at a radius of $25 \mathrm{~mm}$ as parts in $10^{4}$ of the Sextupole field at $26 \mathrm{~mm}$.

NOTEz $B 2=1 / 2 \mathrm{~B}^{n}$.

-Work performed under Contract No. DE-AC02-76CH00016 with the U.S. Department of Energy 